\title{
PEMBELAJARAN BAHASA INDONESIA BERBASIS TEKS DI SMA NEGERI 1 SINGARAJA
}

\author{
A A N Bagus Janitra Dewanta ${ }^{1}$, I M Sutama ${ }^{2}$ N M Rai Wisudariani ${ }^{3}$ \\ Prodi Pendidikan Bahasa Indonesia, Jurusan Bahasa Sastra Indonesia dan \\ Daerah, Fakultas Bahasa dan Seni, Universitas Pendidikan Ganesha \\ Singaraja, Indonesia
}

e-mail: agungjanitradewanta17@gmail.com ${ }^{1}$, imadesutamaubd@gmail.com² ${ }^{2}$, rai.wisudariani85@gmail.com ${ }^{3}$

\begin{abstract}
ABSTRAK
Penelitian ini bertujuan untuk mendeskripsikan (1) perencanaan pembelajaran Bahasa Indonesia berbasis teks dan (2) pelaksanaan pembelajaran Bahasa Indonesia berbasis teks di SMA Negeri 1 Singaraja. Penelitian ini menggunakan rancangan penelitian deskriptif kualitatif. Subjek dalam penelitian ini adalah guru Bahasa Indonesia SMA Negeri 1 Singaraja. Objek penelitian ini adalah (1) perencanaan pembelajaran Bahasa Indonesia berbasis teks dan (2) pelaksanaan pembelajaran Bahasa Indonesia berbasis teks di SMA Negeri 1 Singaraja. Data dikumpulkan dengan metode dokumentasi, observasi, dan wawancara (semi terstruktur). Tahapan analisis data meliputi reduksi data, penyajian data, dan, penyimpulan. Hasil penelitian menunjukkan bahwa (1) perencanaan pembelajaran Bahasa Indonesia berbasis teks sudah sesuai dengan Permendikbud No. 22 Tahun 2016 dan terkandung sintak pembelajaran berbasis teks berdasarkan Kemendikbud (2013b: vi). (2) pelaksanaan pembelajaran sudah dilaksanakan sesuai isi skenario pembelajaran dan sintak pembelajaran Bahasa Indonesia berbasis teks sudah tampak.
\end{abstract}

Kata kunci: pembelajaran, berbasis teks.

\begin{abstract}
This research aims to describe (1) planning of text-based Indonesian language learning and (2) the implementation of text-based Indonesian language learning at SMAN 1 Singaraja. This research uses a descriptive qualitative research design. The subjects in this research were Indonesian language teacher at SMAN 1 Singaraja. The objects of this research are (1) planning of text-based Indonesian language learning and (2) the implementation of text-based Indonesian language learning at SMAN 1 Singaraja. The data collected by the methods of documentation, observation, and interviews (semistructured). Stages of data analysis include data reduction, data presentation, and inference. The results of the study show that (1) planning of text-based Indonesian language learning was in appropriate with Permendikbud No. 22 of 2016 and contained the syntax of text-based learning based on the Ministry of Education and Culture (2013b: vi). (2) the implementation of learning has been implemented according to the contents of the learning scenario and the syntax of text-based Indonesian learning already visible.
\end{abstract}

Keywords: learning, text based. 


\section{PENDAHULUAN}

Pembelajaran merupakan segala upaya yang dilakukan oleh guru agar terjadi proses belajar pada diri siswa. Dimyati dan Mudjiono (dalam Sagala, 2012: 62) menyatakan pembelajaran adalah kegiatan guru secara terprogram dalam desain instruksional, untuk membuat siswa belajar secara aktif, yang menekankan pada penyediaan sumber belajar. Artinya, dalam proses pembelajaran guru harus berupaya mengubah masukan berupa siswa yang belum terdidik, menjadi siswa yang terdidik, atau bisa dikatakan terjadinya perubahan tingkah laku pada diri siswa.

Untuk mencapai proses pembelajaran yang optimal dan tujuan pendidikan, diperlukan kurikulum untuk mengatur pembelajaran yang akan dilaksanakan. Kurikulum merupakan suatu program pendidikan yang disediakan untuk membelajarkan siswa. Itu sebabnya, suatu kurikulum harus disusun sedemikan rupa agar maksud atau tujuan pendidikan dapat tercapai.

Kurikulum 2013 sudah dijalankan di semua jenjang pendidikan di Indonesia mulai dari SD, SMP dan SMA hingga ke perguruan tinggi. Menurut Ismawati (2012: 252) Kurikulum 2013 bertujuan agar menghasilkan insan Indonesia yang produktif, inovatif, dan kreatif melalui penguatan sikap, keterampilan dan pengetahuan yang terintegrasi.

Pada Kurikulum 2013 ini pembelajaran Bahasa Indonesia menjadi mata pelajaran yang diwajibkan. Pembelajaran Bahasa Indonesia pembelajaran berbasis teks. Pembelajaran berbasis teks adalah pembelajaran yang menjadikan teks sebagai dasar, asas, pangkal dan tumpuan (Sufanti, 2013). Dengan asumsi tersebut, fungsi pembelajaran Bahasa Indonesia adalah mengembangkan kemampuan memahami dan menciptakan teks karena komunikasi terjadi dalam teks atau pada tataran teks.

Untuk mengoptimalkan terlaksananya kegiatan pembelajaran Bahasa Indonesia berbasis teks, maka peran guru sangatlah penting. Dalam implementasi pembelajaran Bahasa Indonesia berbasis teks, lebih berorientasi pada siswa dan proses pembelajaran yang dilaksanakan guru menjadi hal yang sangat penting untuk membuat siswa mampu menguasai materi dan kompetensi. Jelaslah bahwa dalam pembelajaran seorang guru harus mampu membuat siswa menguasai materi sesuai kompetensi yang ingin dicapai, atau dengan kata lain guru tersebut harus profesional.

Meskipun semua jenjang Pendidikan di Indonesia, khususnya jenjang SMA/SMK telah menerapkan Kurikulum 2013, namun masih banyak sekolah yang belum sepenuhnya optimal dalam melaksanakan hal tersebut. Dimulai dari penyusunan Rencana Pelaksanaan Pembelajaran (RPP) yang belum dilakukan dengan baik oleh para guru, sampai pada tahap pembelajaran pun guru belum sepenuhnya menjalankan pembelajaran Bahasa Indonesia berbasis teks dengan baik dan optimal.

Berdasarkan permasalahan di atas, untuk memberikan referensi kepada guru mata pelajaran Bahasa Indonesia dalam menyusun perencanaan dan melaksanakan pembelajaran Bahasa Indonesia berbasis teks, peneliti tertarik dan perlu untuk melakukan penelitian dengan judul "Pembelajaran Bahasa 
Indonesia Berbasis Teks di SMA Negeri 1 Singaraja"

\section{METODE PENELITIAN}

Tercapai tidaknya tujuan penelitian, sangat bergantung pada metode yang digunakannya. Metode penelitian yang digunakan dalam penelitian ini mencakup (1) rancangan penelitian, (2) subjek dan objek penelitian, (3) metode pengumpulan data, (4) instrumen penelitian, dan (5) teknik analisis data. Rancangan penelitian yang digunakan dalam penelitian ini adalah rancangan deskriptif kualitatif. Rancangan penelitian deskriptif kualitatif ini dipilih karena rancangan penelitian ini mampu menggambarkan secara keseluruhan pembelajaran Bahasa Indonesia berbasis teks. Subjek dalam penelitian ini adalah guru Bahasa Indonesia di SMA Negeri 1 Singaraja. Objek dalam penelitian ini adalah pembelajaran Bahasa Indonesia berbasis teks.

Pada pengumpulan data penelitian, peneliti menggunakan metode dokumentasi, observasi, dan wawancara (semi terstruktur) Metode dokumentasi digunakan untuk menjawab dari permasalahan pertama yang diteliti, yaitu perencanaan pembelajaran Bahasa Indonesia berbasis teks. Metode observasi digunakan untuk menjawab dari permasalahan kedua yang diteliti, yaitu pelaksanaan pembelajaran Bahasa Indonesia berbasis teks. Penggunaan metode wawancara (semi terstruktur) merupakan lanjutan dari metode observasi. Dalam metode ini, digunakan untuk mencari data yang tidak didapatkan melalui metode dokumentasi dan observasi. Instrumen yang digunakan yaitu: 1) catatan dokumentasi, 2) catatan lapangan (field note), dan 3) pedoman wawancara. Data-data yang telah dikumpulkan menggunakan instrumen yang ada, selanjutnya akan dianalisis menggunakan metode analisis data. Data mengenai perencanaan dan pelaksanaan pembelajaran dianalisis dengan deskriptif kualitatif. Pertama yang dilakukan oleh peneliti yaitu melihat secara langsung kegiatan pembelajaran Bahasa Indonesia berbasis teks. Kedua peneliti merekam dan mencatat kegiatan yang dilakukan guru dan siswa menggunakan lembar observasi.

\section{HASIL PENELITIAN}

Hasil penelitian ini mencakup perencanaan pembelajaran dan pelaksanaan proses pembelajaran Bahasa Indonesia berbasis teks di SMA Negeri 1 Singaraja. Perencanaan pembelajaran berbasis teks yang dilakukan oleh guru di SMA Negeri 1 Singaraja terdiri atas beberapa kegiatan, yaitu penyusunan perangkat pembelajaran yang meliputi rencana pelaksanaan pembelajaran, media, evaluasi, dan perancangan strategi blended learning berbasis schoology.

Dalam

pembelajaran, pembelajaran berbasis teks dieksplisitkan dalam aktivitas pembelajaran. Dalam mewujudkan aktivitas pembelajaran berbasis teks, langkah pengembangan teks dalam pembelajaran bahasa Indonesia dilakukan oleh guru melalui empat tahapan. Tahapan/sintak tersebut terdiri atas: (1) tahap pembangunan konteks, (2) tahap pemodelan teks, (3) tahap pembuatan teks secara bersama-sama, dan (4) tahap pembuatan teks secara mandiri.

Pada tahap pembangunan konteks, langkah awal yang dilakukan oleh guru bersama siswa 
adalah mengarahkan pemikiran siswa ke dalam pokok persoalan yang dibahas pada pembelajaran. Tahap pembangunan konteks telah dituangkan oleh guru dalam RPP pada bagian apersepsi. Tahap kedua adalah pemodelan teks. Tahap pemodelan teks berisi tentang pembahasan teks yang diberikan sebagai model pembelajaran. Pada Pembahasan diarahkan kepada semua aspek kebahasaan yang membentuk teks proposal secara keseluruhan. Tahap ketiga adalah pembuatan teks secara bersama-sama. Pada tahap ini guru menugaskan siswa secara berkelompok untuk menyusun teks seperti yang ditunjukkan pada model sesuai dengan struktur teks proposal. Tahap terakhir adalah pembuatan teks secara mandiri. Pada tahap ini, siswa ditugaskan untuk membuat teks secara mandiri berdasarkan pengalaman membuat teks secara berkelompok. Dengan demikian, diharapkan siswa dapat mengaktualisasikan diri dengan menggunakan teks sesuai dengan jenis dan ciri-ciri seperti yang ditunjukkan pada tahap pemodelan teks.

Dalam RPP Bahasa Indonesia berbasis teks, guru membuat media pembelajaran sebagai sarana untuk menyampaikan isi/materi pembelajaran. Media yang dibuat oleh guru berupa Power Point dan teks proposal penelitian. Media Power Point dipilih oleh guru selain karena kepraktisannya, juga dapat menjangkau kelompok banyak, tempo dan cara penyajiannya bisa disesuaikan, dan dapat digunakan secara berulang-ulang, serta lebih menarik minat siswa untuk memperhatikan materi pembelajaran.

Pada media teks proposal penelitian, teks yang digunakan dalam pembelajaran tidak hanya terpaku pada buku ajar, tetapi guru juga membuat teks sendiri yang kontekstual. Guru membuat sendiri contoh teks proposal penelitian sederhana yang baik dan benar Implementasi Program Gerakan Literasi Sekolah (GLS) di SMA Negeri 1 Singaraja yang digunakan sebagai media dalam pembelajaran. Penyusunan teks dilakukan oleh guru agar pengetahuan siswa mengenai contoh teks proposal tidak hanya sebatas contoh pada buku ajar saja. Penentuan teks proposal yang didasarkan pada teks yang disusun oleh guru mengandung unsur-unsur teks proposal yang ideal dan benar, sehingga dalam pembelajaran siswa mengetahui contoh teks proposal yang sederhana dan mengandung keseluruhan unsur-unsur teks proposal.

Dalam perangkat pembelajaran yang disusun guru, evaluasi pembelajaran dilakukan dengan menggunakan tes dan nontes, dalam bentuk tertulis maupun lisan. Keseluruhan evaluasi pembelajaran baik tes dan nontes, dalam bentuk tertulis maupun lisan telah disesuaikan dengan materi pembelajaran yang terangkum dalam sintaks pembelajaran Bahasa Indonesia berbasis teks.

Pengevaluasian hasil belajar berupa tes digunakan untuk mengukur pengetahuan dan pemahaman siswa secara keseluruhan mengenai materi teks proposal, yaitu pada kegiatan tes tulis atau ulangan harian pada akhir pertemuan (pertemuan kedelapan). Sedangkan evaluasi dalam bentuk nontes digunakan untuk mengukur pemahaman siswa mengenai maksud dan tujuan teks proposal, bagian-bagian penting teks proposal, kebermanfaatan dan inspirasi setelah membaca teks proposal, fitur kebahasaan teks proposal, 
presentasi hasil diskusi kelompok, dan menjawab soal-soal pada buku paket yang dilakukan secara lisan. Secara keseluruhan evaluasi pembelajaran berbasis teks yang dirancang oleh guru adalah untuk mengevaluasi pembelajaran berbasis teks.

Strategi yang dirancang oleh guru dalam pembelajaran berbasis teks adalah blended learning berbasis schoology. Pemilihan strategi ini didasarkan pada kepraktisan dan keefektifan penyampaian sumber belajar dalam pembelajaran Bahasa Indonesia berbasis teks, serta tuntutan dari kebijakan sekolah untuk menggunakan e-learning dalam pembelajaran.

Pembelajaran blended learning berbasis schoology dapat memenuhi kebutuhan dalam pembelajaran berbasis teks. Selain secara visual dan fungsionalnya mudah digunakan, schoology dilengkapi dengan berbagai macam pembelajaran yang hampir sama dengan di kelas. Dalam pembelajaran guru menggunakan fitur resources untuk mengunggah sumber belajar berupa teks proposal penelitian, fitur courses untuk mengunggah soal, dan fitur groups untuk mengumpulkan tugas-tugas siswa. Sehingga guru Bahasa Indonesia di SMA Negeri 1 Singaraja menggunakan strategi pembelajaran blanded learning berbasis schoology dalam perencanaan pembelajaran berbasis teks.

Data yang diperoleh mengenai pelaksanaan pembelajaran Bahasa Indonesia berbasis teks, peneliti melakukan observasi terhadap kegiatan pembelajaran di kelas dengan mencatat dan merekam seluruh kegiatan. Pelaksanaan pembelajaran Bahasa Indonesia berbasis teks pada materi teks proposal, dilaksanakan selama delapan kali pertemuan. Secara umum pelaksanaan pembelajaran yang dilakukan oleh guru dapat dikatakan baik dan optimal. Ketercapaian pelaksanaan pembelajaran tersebut dapat dibuktikan dari kesesuaian pelaksanaan pembelajaran dengan RPP yang dibuat, terdapat pendekatan saintifik dalam pembelajaran $(5 \mathrm{M})$, terlaksananya empat tahapan pembelajaran Bahasa Indonesia berbasis teks berdasarkan Kemendikbud (2013b: vi), serta pelaksanaan strategi pembelajaran blended learning berbasis schoology yang optimal.

\section{PEMBAHASAN}

Pembahasan hasil penelitian ini terkait dengan perencanaan pembelajaran dan pelaksanaan pembelajaran Bahasa Indonesia berbasis teks di SMA Negeri 1 Singaraja.

Temuan penting terkait rencana pelaksanaan pembelajaran Bahasa Indonesia berbasis teks yang perlu dibahas dalam penelitian ini, menyangkut (1) penyusunan perangkat pembelajaran, yang meliputi rencana pelaksanaan pembelajaran, media, evaluasi pembelajaran, dan (2) strategi pembelajaran blanded learning berbasis schoology.

Pembelajaran Bahasa Indonesia berbasis teks membutuhkan perencanaan yang matang karena teks digunakan sebagai media utama dalam pembelajaran. Temuan ini senada dengan apa yang disampaikan oleh Pribadi (2009: 86) yang menyatakan, bahwa keberhasilan suatu program kegiatan sangat ditentukan oleh seberapa besar kualitas mendesain atau membuat perencanaan yang dibuatnya.

Perencanaan pembelajaran pada dasarnya merupakan bentuk keseriusan guru 
dalam mendesain aktivitas pembelajaran yang tergambar dari awal sampai akhir. Bentuk pembelajaran yang dimaksud merupakan sesuatu yang menggambarkan adanya pola berpikir sekaligus sebagai keseluruhan konsep yang saling berkaitan. Sehingga tingkat keberhasilan pembelajaran akan sangat signifikan jika direncanakan dengan baik.

Hasil yang baik adalah ketika direncanakan dengan baik. Dalam rencana pelaksanaan pembelajaran, pembelajaran berbasis teks tersebut dapat dimasukkan ke dalam sintak pembelajaran. Hal ini berkaitan dengan hakikat pembelajaran Bahasa Indonesia berbasis teks, yaitu pembelajaran yang menjadikan teks sebagai dasar, asas, pangkal dan tumpuan (Sufanti, 2013), sehingga guru harus mengelola teks dalam pembelajaran melalui tahapan-tahapan pelaksanaan. Untuk memahami teks dan mampu mengaktualisasikan pengetahuan mengenai teks, siswa harus melalui tahapan atau sintak pembelajaran berbasis teks. Hal tersebutlah yang menyebabkan sintak sangat penting untuk dituangkan dalam RPP.

Dalam

pembelajaran, guru menyusun sendiri teks yang digunakan sebagai media dalam pembelajaran. Hal ini menunjukkan bahwa kekontekstualan teks sangat berpengaruh terhadap proses dan hasil belajar pembelajaran berbasis teks. Temuan ini senada dengan apa yang disampaikan oleh Sujana (2014) yang menyatakan, bahwa pembelajaran yang kontekstual membuat siswa menjadi tidak kesulitan dalam memahami isi pembelajaran. Selain mengaitkan materi dengan kehidupan sehari-hari siswa, di dalam pembelajaran kontekstual siswa juga mendapatkan pembelajaran yang bermakna (Johnson, 2008). Pembelajaran bermakna yang didapatkan oleh siswa pada saat pembelajaran membuat siswa lebih mengingat materi pembelajaran tersebut sehingga dapat mempengaruhi hasil belajar yang diperoleh.

Selain media pembelajaran yang kontekstual, dalam perangkat pembelajaran guru juga merancang evaluasi pembelajaran. Evaluasi pembelajaran dimaksudkan untuk mengukur apakah tujuan atau kemampuan yang sudah ditetapkan dapat tercapai. Pernyataan ini senada dengan Ralp Tyler (dalam Arikunto, 2011: 3) mengatakan bahwa "Evaluasi merupakan sebuah proses pengumpulan data untuk menentukan sejauh mana, dalam hal apa, dan bagaimana tujuan pendidikan sudah tercapai. Jika belum, bagaimana yang belum dan apa sebabnya". Masih di dalam buku yang sama, definisi yang lebih luas dikemukakan oleh dua orang ahli, yakni Cronbach dan Stufflebeam. Tambahan definisi tersebut adalah, bahwa proses evaluasi bukan sekadar mengukur sejauh mana tujuan tercapai, tetapi digunakan untuk membuat keputusan.

Evaluasi merupakan aspek yang penting dalam perencanaan pembelajaran yang berguna untuk mengukur, menilai, dan memutuskan seberapa jauh tujuan pembelajaran telah tercapai. Guru melakukan evaluasi terhadap materi yang telah dijelaskan dan evaluasi inilah yang menunjukkan bahwa siswa itu paham atau tidak sehingga evaluasi sangat diperlukan setiap kali pertemuan. Dalam perangkat pembelajaran yang telah disusun oleh guru, adapun evaluasi yang digunakan berupa tes dan nontes. Evaluasi berupa tes dilakukan guru pada akhir pertemuan materi teks proposal yang mencakup 
keseluruhan isi materi. Sedangkan evaluasi berupa nontes dilakukan guru pada setiap kali pertemuan, baik presentasi hasil diskusi kelompok maupun menjawab soal bersama secara lisan.

Selain penyusunan perangkat pembelajaran yang meliputi RPP, media, dan evaluasi, hal lain yang dilakukan oleh guru adalah menentukan strategi dalam pembelajaran. Strategi yang dirancang oleh guru adalah blended learning berbasis schoology. Selain secara visual dan fungsionalnya mudah untuk digunakan, schoology juga dilengkapi dengan berbagai fitur yang dapat memudahkan guru dan siswa dalam proses pembelajaran. $\mathrm{Hal}$ ini tentu berpengaruh terhadap keberhasilan pembelajaran. Pernyataan tersebut senada dengan Semler (dalam Susanto, 2016) yang menyatakan, bahwa blended learning combines the best aspects of online learning, structured face to face activities, and real world practice. Online learning systems, classroom training, and on-the-job experience have major drawbacks by themselves. The blended learning approach uses the strengths of each to counter the others' weaknesses. Blended learning merupakan kombinasi keuntungan dari online learning, pembelajaran tatap muka dan pengalaman di dunia nyata. Kombinasi dari penggabungan semua komponen dapat memberikan keuntungankeuntungan tersendiri dalam hasil pembelajaran dari peserta didik. Berdasarkan pernyataan tersebut, jelas bahwa strategi pembelajaran blended learning berbasis schoology merupakan pilihan yang tepat oleh guru untuk meningkatkan hasil belajar siswa.

Selain keuntungan dan kepraktisan penggunaan strategi blended learning berbasis schoology, jika dihubungkan dengan pembelajaran berbasis teks yang menggunakan media teks sebagai media utamanya, diperlukan banyak sekali kertas untuk mencetak media berupa teks proposal. Hal ini tentu tidak praktis, tidak efisien, dan tidak fleksibel dalam pembelajaran, sehingga dengan menggunakan fitur resources dalam schoology untuk mengunggah teks proposal tentu akan jauh lebih praktis, efisien dan fleksibel untuk diakses dan diunduh oleh siswa. Penggunaan strategi blended learning berbasis schoology dalam pembelajaran berbasis teks didasari oleh kepraktisan, keefisienan, dan fleksibilitas.

Temuan penting terkait pelaksanaan pembelajaran yang perlu dibahas dalam penelitian ini, adalah (1) pembelajaran yang dilakukan oleh guru sudah sesuai dengan RPP yang dibuat dan sesuai dengan pendekatan saintifik pada Kurikulum 2013, yaitu mengamati, menanya, mengumpulkan informasi, mengolah informasi, dan mengomunikasikan (5M), (2) pembelajaran yang dilakukan oleh guru sudah mengandung empat sintak pembelajaran Bahasa Indonesia berbasis teks, yang meliputi tahap pembangunan konteks, tahap pemodelan teks, tahap pembuatan teks secara bersama-sama, dan tahap pembuatan teks secara mandiri, dan (3) pembelajaran yang dilakukan oleh guru menggunakan strategi blended learning berbasis schoology sudah dapat dilaksanakan dengan baik dan optimal.

Pelaksanaan pembelajaran merupakan implementasi dari rencana pelaksanaan pembelajaran (Permendikbud No. 65 Tahun 2013) yang meliputi, kegiatan pendahuluan, kegiatan inti, dan kegiatan penutup. Oleh karena itu, dalam pelaksanaannya akan sangat 
bergantung pada perencanaan pembelajaran. Perencanaan pembelajaran yang baik akan berimplikasi pada pelaksanaan pembelajaran yang baik pula. Pelaksanaan pembelajaran Bahasa Indonesia berbasis teks yang dilakukan guru di kelas XI Bahasa di SMA Negeri 1 Singaraja sudah mengacu pada langkah-langkah pembelajaran dalam RPP yang disusun oleh guru serta sesuai dengan pendekatan saintifik (5M).

Sesuai dengan Permendikbud No. 65 tahun 2013, pada kegiatan pendahuluan, guru memberikan pembelajaran yang ditujukan untuk memfokuskan perhatian siswa agar berpatisipasi aktif dalam pembelajaran. Dalam hal ini, guru mengawali pembelajaran dengan memberi salam pembuka dan apersepsi. Apersepsi yang dilakukan guru yaitu dengan mengaitkan pengalaman siswa atau pengetahuan siswa sebelumnya dengan yang akan dipelajari melalui video dan pertanyaan-pertanyaan. Selain itu guru juga menyampaikan kompetensi dasar, tujuan pembelajaran, dan manfaat yang diperoleh siswa dalam kehidupan sehari-hari setelah mempelajari materi teks proposal.

Kemudian

pembelajaran berlanjut pada kegiatan inti, dengan pendekatan saintifik yaitu mengamati, menanya, mengumpulkan informasi, mengolah informasi, dan mengomunikasikan (5M). Pada kegiatan mengamati, guru memberikan kesempatan kepada siswa secara berkelompok untuk mengamati contoh teks proposal penelitian dan kegiatan. Pada kegiatan menanya, guru selalu membuat suasana kelas menjadi santai, tetapi serius untuk mengikuti pelajaran. Dengan demikian, banyak siswa yang berani bertanya berkaitan dengan materi teks proposal penelitian maupun proposal kegiatan yang telah mereka amati. Dengan cara belajar demikian, pada kegiatan mengamati dan menanya siswa menjadi aktif dan kritis dalam pembelajaran.

Kegiatan selanjutnya adalah
mengumpulkan informasi dan mengolah informasi. Siswa diberikan kesempatan berdiksusi secara kelompok untuk kembali memahami dan diberikan tugas untuk menganalisis sebuah teks proposal. Pada tahap ini, peserta didik melakukan analisis terhadap teks proposal dan mengaitkan hasil analisisnya dengan teori yang telah mereka pelajari.

Kegiatan terakhir ialah mengomunikasikan, dalam kegiatan ini peserta didik diberikan kesempatan untuk menyampaikan hasil diskusinya dan memberikan pendapat mengenai hasil diskusi kelompok lain. Guru selanjutnya memberikan komentar dan apresiasi kepada seluruh siswa, sehingga pembelajaran dapat berjalan dengan baik dan kondusif.

Setelah kegiatan inti selesai dilaksanakan, kemudian dilanjutkan ke bagian penutup. Pada kegiatan penutup, guru bersama siswa menyimpulkan pembelajaran. Setelah guru bersama siswa menyimpulkan pembelajaran, guru kemudian memberikan refleksi. Refleksi pembelajaran merupakan komponen kegiatan yang dilaksanakan setelah proses pembelajaran dengan tujuan untuk menilai dan mengamatii apa yang telah terjadi selama pembelajaran berlangsung. Refleksi yang dilakukan oleh guru yaitu melalui lisan. Guru mengajukan pertanyaan kepada siswa, dengan minta pendapat siswa mengenai cara mengajar, suasana pembelajaran, pemahaman pembelajaran, ataupun meminta kritik dan saran kepada 
siswa terhadap pembelajaran dan dirinya. Hal ini dilakukan menjelang pembelajaran berakhir sehingga tidak menggangu pembelajaran.

Kesesuaian pelaksanaan pembelajaran dengan rencana pelaksanaan pembelajaran yang disusun oleh guru, selain menandakan bahwa RPP yang sudah baik juga menandakan bahwa guru mampu berpikir secara futuristik. Berdasarkan pernyataan tersebut, guru mampu merancang rencana pelaksanaan pembelajaran secara futuristik dengan tetap mempertimbangkan realitasnya dalam pelaksanaan pembelajaran.

Selain kesesuaian pelaksanaan pembelajaran dengan RPP yang dibuat oleh guru dan terdapat pendekatan saintifik pada Kurikulum 2013, pelaksanaan pembelajaran Bahasa Indonesia berbasis teks yang dilakukan oleh guru di SMA Negeri 1 Singaraja juga sudah mengandung empat sintak pembelajaran Bahasa Indonesia berbasis teks berdasarkan Kemendikbud (2013b: vi), yang meliputi (1) tahap pembangunan konteks, (2) tahap pemodelan teks, (3) tahap pembuatan teks secara bersama-sama, dan (4) tahap pembuatan teks secara mandiri.

Pada tahap pertama yaitu tahap pembangunan konteks, guru membangun pemahaman peserta didik terhadap tema pembelajaran. Dalam membangun konteks, peningkatan pemahaman dilakukan secara eksplisit oleh guru dan peserta didik dalam proses pembelajaran. Tahap membangun konteks pada pembelajaran teks proposal adalah ketika guru mengaitkan pengalaman siswa atau pengetahuan siswa sebelumnya dengan yang akan dipelajari melalui video dan pertanyaan-pertanyaan.

Tahap pembangunan konteks

yang dilaksanakan pada

pembelajaran teks proposal di kelas XI Bahasa SMA Negeri 1 Singaraja sudah sesuai dengan materi membangun konteks itu sendiri, yang menyatakan bahwa tahap ini berguna untuk menyiapkan konteks dan membangun pembelajaran (Kemendikbud, 2013b: vi).

Pada tahap kedua yaitu tahap pemodelan teks. Strategi pemodelan teks mempunyai tiga tahap dalam proses menulis, yaitu membaca teks model, menganalisis teks model, dan berlatih menulis dengan meniru konstruksi teks model. Tahap pemodelan teks pada pembelajaran teks proposal adalah saat guru meminta peserta didik untuk mengamati contoh teks proposal. Kemudian guru dan peserta didik bertanya jawa mengenai unsurunsur penting yang terdapat pada teks proposal tersebut. Setelah itu guru memberikan contoh teks proposal lainnya dan kemudian menugaskan peserta didik secara berkelompok untuk menganalisis unsur-unsur penting pada teks proposal.

Tahap pemodelan teks pada pembelajaran teks proposal ini sudah sesuai dengan teori yang ada pada tahap pemodelan teks berdasarkan Kemendikbud, (2013b: vi). Setiap unsur yang ada pada materi menelaah model sudah terlaksana sesuai dengan teorinya, mulai dari tahap pertama sampai terakhir.

Tahapan ketiga pembelajaran Bahasa Indonesia berbasis teks adalah pembuatan teks secara bersama-sama. Pada tahap ini guru meminta peserta didik untuk duduk berkelompok, setiap kelompok terdiri dari empat sampai lima orang. Guru meminta peserta didik berdiskusi dengan anggota kelompoknya untuk membuat judul dan rumusan masalah proposal penelitian. Setelah selesai, guru meminta peserta didik 
secara berkelompok untuk mempresentasikan hasil diskusinya, kemudian guru bersama kelompok penyaji berdiskusi, sehingga judul dan rumusan masalah proposal penelitian dapat disempurnakan dan disepakati oleh kedua pihak.

Tahap pembuatan teks secara bersama-sama yang dilaksanakan pada pembelajaran teks proposal di kelas XI Bahasa SMA Negeri 1 Singaraja juga sudah sesuai dengan teori yang ada yang menyatakan, bahwa pada tahap pembuatan teks secara bersama-sama harus dilaksanakan secara bersama-sama oleh peserta didik dengan bimbingan dari guru.

Tahapan terakhir pembelajaran Bahasa Indonesia berbasis teks adalah pembuatan teks secara mandiri. Pada tahap ini guru memfasilitasi peserta didik secara berkelompok untuk mengamati teks proposal yang telah dibuat bersama-sama, untuk kemudian meminta peserta didik memproduksi teks proposal lengkap secara mandiri. Jadi, proses pembuatan teks secara mandiri pada teks proposal ini juga sudah sesuai dan berkaitan dengan teori yang ada, bahwa pada kegiatan mengonstruksi mandiri peserta didik dituntut untuk bisa mengahasilkan sebuah teks proposal karya sendiri.

Berdasarkan pembahasan mengenai pelaksanaan pembelajaran di atas dapat disimpulkan, bahwa pelaksanaan pembelajaran Bahasa Indonesia berbasis teks yang dilaksanakan oleh guru Bahasa Indonesia di SMA Negeri 1 Singaraja sudah baik dan sesuai dengan keempat sintak pembelajaran Bahasa Indonesia berbasis teks.

Selain dari kesesuaian pelaksanaan dengan perencanaan dan terlaksananya empat sintak pembelajaran berbasis teks, dalam pelaksaan pembelajaran strategi yang dirancang oleh guru berupa blended learning berbasis schoology juga telah terlaksana dengan baik dan sesuai dengan perencanaan. Strategi pembelajaran blended learning berbasis schoology dalam pelaksanaannya mampu membuat pengaruh yang signifikan terhadap pembelajaran berbasis teks. Dalam proses pembelajaran menggunakan blended learning berbasis schoology membuat seluruh siswa menjadi lebih antusias, hal ini dikarenakan pembelajaran menjadi lebih praktis, efektif, dan efisien. Siswa menjadi mudah untuk mendapatkan media pembelajaran berupa teks proposal penelitian yang diberikan oleh guru dan dapat mereka unduh pada fitur resources melalui Hand Phone maupun laptop. Selain itu, schoology juga memudahkan siswa dalam mengumpulkan hasil diskusi kelompok maupun tugas-tugas lainnya melalui fitur groups dalam bentuk softcopy yang dapat siswa kerjakan melalui HandPhone atau laptop. Hal ini tentu membuat pembelajaran menjadi lebih praktis, efektif dan efisien.

Berdasarkan pembahasan mengenai pelaksanaan pembelajaran di atas, dapat disimpulkan bahwa pelaksanaan pembelajaran Bahasa Indonesia berbasis teks yang dilaksanakan oleh guru Bahasa Indonesia di SMA Negeri 1 Singaraja sudah baik dan sesuai dengan rencana pelaksanaan pembelajaran yang dibuat, mengandung empat sintak pembelajaran Bahasa Indonesia berbasis teks, dan kesesuaian strategi pembelajaran yang dipilih, yaitu blended learning berbasis schoology.

\section{SIMPULAN DAN SARAN}

Berdasarkan hasil penelitian dan pembahasan maka dapat 
disimpulkan bahwa pembelajaran Bahasa Indonesia berbasis teks, yang dirinci menjadi perencanaan pembelajaran dan pelaksanaan pembelajaran di SMA Negeri 1 Singaraja sudah dilaksanakan dengan baik dan optimal. Berdasarkan uraian mengenai hasil penelitian dan pembahasan, adapun simpulan yang penulis sampaikan sebagai berikut.

(1) Perencanaan pembelajaran Bahasa Indonesia berbasis teks yang dilakukan oleh guru di SMA Negeri 1 Singaraja terdiri atas beberapa kegiatan, yaitu penyusunan perangkat pembelajaran yang meliputi rencana pelaksanaan pembelajaran, media, evaluasi, dan perancangan strategi blended learning berbasis schoology. Dalam penyusunan rencana pelaksanaan pembelajaran, pembelajaran berbasis teks dipaparkan oleh guru dalam aktivitas pembelajaran melalui empat sintak pembelajaran berbasis teks. Perancangan media pembelajaran berbasis teks dilakukan oleh guru dengan menyusun teks proposal yang kontekstual. Kegiatan evaluasi berbasis teks yang dilakukan oleh guru dengan menyiapkan instrumen evaluasi dalam bentuk tulis maupun lisan untuk mengukur pemahaman siswa mengenai teks yang dipelajari. Guru merancang strategi pembelajaran blended learning dengan memanfaatkan portal schoology untuk menyediakan sumber belajar berupa teks.

(2) Pelaksanaan pembelajaran berbasis teks yang dilakukan oleh guru sesuai dengan langkah-langkah pembelajaran yang tertuang dalam RPP. Pelaksanaan pembelajaran berbasis teks dilakukan oleh guru dengan menggunakan teks untuk memahami isi teks, struktur dan sistematika teks, kaidah kebahasaan teks, pembuatan teks secara terbimbing, dan bermuara pada pembuatan teks secara mandiri.

Berdasarkan uraian mengenai hasil penelitian dan pembahasan, adapun saran yang penulis sampaikan sebagai berikut.

(1) Bagi guru Bahasa Indonesia. Hasil temuan pada penelitian ini menunjukkan perencanaan dan pelaksanaan pembelajaran Bahasa Indonesia di SMA Negeri 1 Singaraja sudah baik dan mengarah pada pembelajaran berbasis teks. Peneliti menyarankan pada guru agar selektif memilih dan menyusun teks yang digunakan.

(2) Bagi peneliti lain. Penelitian ini sebatas pada kajian perencanaan dan pelaksanaan. Kajian mengenai assesmen dalam pembelajaran berbasis teks belum menjadi fokus dalam kajian ini. Peneliti lain diharapkan melakukan kajian terkait dengan assesmen pembelajaran berbasis teks.

(3) Bagi Sekolah. Hasil penelitian ini menunjukkan bahwa perencanaan dan pelaksanaan pembelajaran Bahasa Indonesia berbasis teks sangat penting untuk dipahami dan dilaksanakan dengan baik oleh guru, sehingga diperlukan pelatihan mengenai pembelajaran berbasis teks.

\section{DAFTAR PUSTAKA}

Arikunto, Suharsimi. 2011. DasarDasar Evaluasi Pendidikan Evaluasi Pendidikan. Edisi Revisi, Cetakan kesebelas. Jakarta: Bumi Aksara.

Johnson, E.B. 2008. Contextual teaching \& learning menjadikan kegiatan belajarmengajar mengasyikkan dan bermakna. Bandung: Mizan Learning Center (MLC). 
Kemendikbud. 2013. Permendikbud No. 65 tentang Standar Proses Pendidikan Dasar dan Menengah. Jakarta: Kementerian Pendidikan dan Kebudayaan.

Kemendikbud. 2016. Permendikbud Nomor 22 Tahun 2016 Tentang Standar Proses Pendidikan Dasar Dan Menengah. Jakarta: Kementerian Pendidikan dan Kebudayaan.

Permendikbud No. 65 Tahun 2013 $\begin{array}{lrr}\text { Tentang Standar Proses } \\ \text { Pendidikan } & \text { Dasar dan }\end{array}$ Menengah. Jakarta: Kementerian Pendidikan dan Kebudayaan.

Pribadi, Benny A. 2009. Model disain Sistem Pembelajaran. Jakarta: Dian rakyat.

Sagala, Saiful. 2012. Konsep dan Makna Pembelajaran: Untuk Membantu Memecahkan Problematika Belajar dan Mengajar. Bandung: Alfabeta.

Sufanti, Main. 2013. "Pembelajaran Bahasa Indonesia Berbasis Teks: Belajar Dari Ohio Amerika Serikat".

http://publikasiilmiah.ums.ac.id diakses pada Selasa 14 Mei 2019.

Susanto, Dias Febryastuti. 2016. Penggunaan Metode Blended Learning dengan Media Schoology untuk Meningkatkan Self Regulated Learning Siswa $X$ RPL 1 SMKN 1 Tengaran. Salatiga: Universitas Kristen Satya Wacana. 